\title{
Adolescents' Trusts in Various Facebook Friends and the Differences in Those Trusts between Parental Awareness of Adolescents' Contacts with Friends
}

\author{
Hsien-Chang Tsai \\ Department of Biology, National Changhua University of Education \\ Taiwan
}

Shih-Hsiung Liu (Corresponding author)
Center for Teacher Education, National Changhua University of Education

No.1 Jin-De Road, Changhua city 500, Taiwan

Tel: 886-4-7232105. E-mail: shsiung@cc.ncue.edu.tw

Received: June 5, 2013 Accepted: June 27, $2010 \quad$ Published: July 9, 2013

doi:10.5296/ire.v1i1.3818 URL: http://dx.doi.org/10.5296/ire.v1i1.3818

\begin{abstract}
The study aims to examine the Taiwanese adolescents' trusts in various friends and the differences in those trusts between parental awareness of adolescents' Facebook use for contacting friends. A survey method was utilized to collect the data related to parental awareness according to adolescents' self-reports, and adolescents' trust in five types of Facebook friends. A total of 1,120 Taiwanese adolescents were invited to fill in a validated questionnaire that consisted of items on parental awareness and trust scales in five types of Facebook friends. Of the sample, 1120 questionnaires were valid. Data were analyzed using Friedman test and one-way analysis of variance. The study determines that the closer the friends were, the more trust adolescents exhibited in them. Moreover, the study concludes that Taiwanese adolescents who did not tell parents about the content of Facebook use exhibited higher trust in friends than those who told parents anything. Since the majority of adolescents put more trust in closer friends with less willing to tell their parents about contacts with Facebook friends, the parents need to be actively concerned their adolescents
\end{abstract}


on Facebook use. The study contributes to the literature by providing a viewpoint, more trust adolescents put in friends, less awareness their parents had, for adolescents using Facebook to contact friends.

Keywords: adolescents, trustfulness, parental involvement, Facebook use, Facebook friends

\section{Introduction}

Facebook use has become increasingly pervasive. Studies have identified that adolescents use Facebook to enhance their social relationships (Ellison, Steinfield, \& Lampe, 2007; Fogel \& Nehmad, 2009; Mesch \& Talmud, 2006; Subrahmanyam, Reich, Waechter, \& Espinoza, 2008; Valkenburg \& Peter, 2007). The above studies report that adolescents use Facebook to contact known friends as well as to reinforce pre-existing friendships. Recently, several studies address an issue on people's trust in Facebook friends as well as potential risks of contacting various online friends (Braun, 2013; Ljepava, Orr, Locke, \& Ross, 2013). Studies also suggested that parents may be insufficiently aware of Internet use of their children (Ang, Chong, Chye, \& Huan, 2012; Chou \& Peng, 2007). When more and more adolescents are involved in Internet social networking, it is worthy of attention on adolescents' trusts in various Facebook friends, along with the level of parental awareness.

Trust is essential for a long-distance relationship development (Mietzner \& Lin, 2005). Trust not only reduces interpersonal tension and conflict (Peterson \& Behfar, 2003), but also enhances interpersonal harmony and cooperation (Valenzuela, Park, \& Kee, 2009). People using Facebook are more willing to share personal information than those using other networking websites mainly because of their trusts in those known friends both in real-life and on Facebook (Chang \& Lee, 2013; Emily, Amy, \& Serge, 2009). However, trust can vary based on a variety of social relationships with friends. Pempek, Yermolayeva and Calvert (2009) categorized groups of Facebook friends as "friends seen regularly", "hometown friends not seen regularly", "college friends not seen regularly", "acquaintances", "siblings and cousins", "strangers", and "parents". Another types of friends were defined by Hsu, Wang and Tai (2011) who investigated Taiwanese users' acquaintanceships after using Facebook and identified as "new friends", "acquaintances", "average friends" and "close friends", differing from that offered by Facebook-friends only, friends of friends, and everyone. People may put a variety of trust in Facebook friends with different degree of social relationships.

According to Socialbakers.com (2013), approximately $60 \%$ of Taiwanese have applied Facebook accounts. It is estimated that approximately a half of Taiwanese adolescents have experienced Facebook use. However, parts of the parents worry about their children's safety on social networking sites, and further do not permit their children to make friends through Internet because Taiwanese local news media often report that adolescents were sexually abused by net-friends.

Ang et al. (2012) in a survey study using a Singapore sample indicated that $70 \%$ of the adolescents reported that their parents knew what they did when they were on the Internet. Another study by Chou and Peng (2007) reached a different conclusion, finding that the 
majority of Taiwanese adolescents did not tell their parents about their online dating; while these adolescents trusted the built online friendships. Moreover, Liu, Yin and Huang (2013) used examples of Taiwanese adolescents as evidence that suggested that Facebook use can facilitate positive relationships with known friends in real-life; however, if adolescents overly use Facebook for interactions, it might reduce the relationships with parents in real-life. The above studies draw attention to Facebook use of adolescents with a factor associated with parental concern, but not suggesting whether adolescents' trusts in various Facebook friends differ due to parental awareness.

On the other hand, Liau, Khoo, and Ang (2005) identified that adolescents who told their parents that they received pornographic junk mail were less likely to be engaged in risky Internet behavior. A study by McCarty, Prawitz, Derscheid and Montgomery (2011) suggested that more time the adolescents spend on Internet interaction, higher trust they hold in net-friends, and more dangerous they would emerge in situation. In other words, the adolescents' trust in Facebook friends is associated with parental awareness of adolescents' Facebook use to contact friends.

Since adolescents use Facebook to facilitate pre-established relationships, they are interacting primarily with known friends. In such cases, trust is probably more likely to occur when adolescents make a verbal communication with a variety of Facebook friends, especially with close friends. However, as previously mentioned, Taiwanese adolescents did not tell their parents about Facebook use, which maybe results in parents' worry about online dating to their child. Adolescents are still developing cognitively, socially, emotionally, physically, and morally. Adolescents' physical and emotional dependence on their parents decreases and moves closer to the friends when they spend increasingly more time with their friends (Bester, 2007). During adolescence, the social development of adolescents, based on peer identification, may reach a crisis point due to a lack of cognitive and/or emotional maturity. Parental involvement is vital for the success of adolescents on development task. At the point of considering parents' worries about potential risk for children, Taiwanese adolescents' trusts in various friends on Facebook and association with their parents' awareness should be clarified. The study aims to examine the Taiwanese adolescents' trusts in various friends and the differences in those trusts between parental awareness of adolescents' Facebook use to contact friends.

\section{Methods}

A survey method was utilized to collect the data related to parental awareness according to adolescents' self-reports, and adolescents' trust in five types of Facebook friends.

\subsection{Sample}

Based on statistical data from the Ministry of Education of Taiwan (2012), there are roughly 844,000 junior high school students ranging in age from 13 to 15 years. According to Cohen, Manion, and Morrison (2007), over 1000 adolescents as a sample size is adequate at the 0.95 confidence level and 3\% confidence intervals. Therefore, via stratified random cluster sampling, the final sample comprised 1440 junior high school students, representing 23 junior 
high schools sampled from the 20 administrative areas (county or city) in Taiwan. Each school received 30-90 copies of questionnaires based on the number of classes in a school. The junior high school students who used Facebook to contact friends were invited to fill in validated questionnaires. Of the sample, 90\% (1298) returned the questionnaire, and 1120 questionnaires were valid.

\subsection{Instruments}

The questionnaires were divided into three sections. The first section was to confirm the types of Facebook friends. The second section focused on whether adolescents told their parents about making contacts with Facebook friends. The third section referred to adolescents' trust in different types of Facebook friends.

The types of Facebook friends referred to a Taiwanese study conducted by Hsu et al. (2011) who categorized the types of friends as close friends, average friends, acquaintances and new friends through interviewing Facebook users. According to their definitions, an acquaintance referred to an individual with whom one has built a very cursory friendship. Average friends referred to individuals with whom users made a bit more interactions and disclosures. In the study by Hsu et al., the number of close friends was the most among four categories. The present study defined close friend as a friend who can listen and share privacy information with an individual, and then revised the name of this type of friends to be "intimate friend". Additionally, this study added an extra type of friend, a romantic friend that brings about a mutual attractive feeling (Connolly \& Konarski, 1994) with a passionate emotional desire, often involving a degree of physical closeness. In terms of closeness on Facebook friends in this study, the types of Facebook friends were categorized as "tending to strangers", "acquaintance friends", "familiar friends", "intimate friends" and "romantic friends". Of which, "romantic friends" category was the closest level.

As for parental awareness of adolescents' Facebook use to contact friends, this study developed two items: (a). Did your parents know whom you are contacting on Facebook? This item was ranged from 1 for "insufficiently know" to 4 for "sufficiently know." (b) Did you tell your parents about the content of using Facebook to contact friends? That was ranged from 1 for "tell parents nothing" to 4 for "tell parents anything."

Moreover, four items were created to measure adolescents' trusts in five types of Facebook friends. The trust scale in each category of Facebook friends has the same four items as follows. (a). Please point out a friend whose characteristic is categorized in the category of Facebook friends and write down his/her nickname. (b). Based on the subject in the first item, I think that his/her expressions of verbal emotions on Facebook wall are actual, (c) I think that his/her postings on Facebook wall are able to be trusted, and (d) I believe that he or she would not lie to me when he or she contacts me. The latter three items were assessed using a five-point scale with 5="very strongly agree" and 1="very strongly disagree". The respondents were asked to response the same three items on trust scale in each category of Facebook friends, respectively. Through reliability analyzed, the reliability coefficients were 0.862 for "tending to strangers", 0.866 for "acquaintance friends", 0.894 for "familiar friends", 0.882 for "intimate friends", and 0.924 for "romantic friends". 


\subsection{Data Analysis}

Data were analyzed using Friedman test and one-way analysis of variance (ANOVA). The means on the trust scale in every category of Facebook friends were calculated. Friedman test was utilized to determine the rank-order among the means on the trust scale in five categories of Facebook friends. Furthermore, by using the data on parental awareness as independent variables and the means on the trust scale as dependent variables, this study utilized one-way ANOVA to examine the differences in adolescents' trusts in each category of Facebook friends between four groups of parental awareness.

\section{Results}

Table 1 lists that the number of each category of Facebook friends according to all valid responses. Because each respondent did not necessarily have every category of Facebook friends, the number of every type of Facebook friends differed. By contrasting these numbers in each category, 472 respondents reported having every category of Facebook friends. Moreover, according to the analytical result of Friedman test, significant rank-orders existed in adolescents' trusts in Facebook friends among five types of Facebook friends $\left(\chi^{2}=537.208\right.$, $d f=4, \mathrm{p}=.000<.05$ ) (Table 1$)$. This finding reveals that adolescents putted the highest trust in romantic friends. The rank-order of the rest follows the closeness order, intimate friends, familiar friends, acquaintance friends, and tending to strangers. Additionally, based on the data about number of each category of Facebook friends in Table 1, the calculated result reveals that Taiwanese adolescents' friends on Facebook tended to be average levels of closeness. Approximately 48\% (536/1120) adolescents reported having the intimate friends. As for the level of "tending to strangers", about 79\% (886/1120) adolescents acknowledged this type of friendships on Facebook.

Table 1. The number of, and mean rank-order of trusts in, five types of Facebook friends

\begin{tabular}{cccc}
\hline types of Facebook friends & number & number of having all types of friends & rank (mean) \\
\hline romantic friends & 536 & $1(3.75)$ \\
intimate friends & 1106 & 472 & $2(3.74)$ \\
familiar friends & 1080 & $3(2.97)$ \\
acquaintance friends & 1050 & $4(2.47)$ \\
tending to strangers & 886 & $5(2.07)$ \\
\hline valid questionnaires & 1120 & \\
\hline
\end{tabular}

Moreover, four groups of parental awareness of whom adolescents are contacting on Facebook were independent variables. Mean scores on trust scale of each category of Facebook friends were dependent variables for one-way ANOVA. The analytical results reveal that significant differences existed between four groups of parental awareness in "tending to strangers" category $(F=3.476, \mathrm{p}=0.016<0.05)$, "intimate friends" category $(F=6.489, \mathrm{p}=0.000<0.05)$, and "romantic friends" category $(F=4.044, \mathrm{p}=0.007<0.05)$. 
Because Levene's Test of Equality of Error Variances shows that the Levene's value for the "tending to strangers" category (Levene's $=3.000, \mathrm{p}=0.030<0.05$ ), and "intimate friends" category (Levene's $=3.569, \mathrm{p}=0.014<0.05$ ) were significant, and that for the "romantic friends" category (Levene's $=0.655, \mathrm{p}=0.580>0.05$ ) was insignificant, post hoc tests in "tending to strangers" category and "intimate friends" category were followed by Games-Howell test, while "romantic friends" category used Schffe's test.

The results of post hoc comparisons exhibit in Table 2. A data reveals that adolescents whose parents knew minority putted more trust than those whose parents sufficiently knew their children's Facebook use in the "tending to strangers" category of Facebook friends. Another finding also shows that adolescents whose parents insufficiently knew their children's Facebook use putted more trust than the other groups in the "intimate friends" category of Facebook friends. In "romantic friends" category of Facebook friends, the adolescents whose parents insufficiently knew their children's Facebook use also putted more trust than the adolescents whose parents knew majority. The above findings raise a concern that adolescents contact their closer friends, especially in intimate and romantic friends, they would be less willing to tell their parents about whom to contact on Facebook.

Table 2. Summary table of one-way ANOVA on various Facebook friends by parental awareness of whom adolescents are contacting on Facebook

\begin{tabular}{lllllll}
\hline $\begin{array}{c}\text { Adolescents' } \\
\text { trust in }\end{array}$ & parents' known & $N$ & $M$ & $\begin{array}{c}\text { Levene's } \\
\text { test }\end{array}$ & $F$ & $\begin{array}{c}\text { Schffe's (Levene's } p>\text {.05) } \\
\text { Games-Howell (Levene's } p<.05)\end{array}$ \\
\hline tending to & insufficiently known (A) & 158 & 2.63 & & & \\
strangers & minority known (B) & 360 & 2.73 & $3.000^{*}$ & $3.476^{*}$ & $\mathrm{~B}>\mathrm{D}$ \\
$N=886$ & majority known (C) & 282 & 2.56 & & & \\
& sufficiently known (D) & 86 & 2.43 & & & \\
acquaintance & insufficiently known (A) & 196 & 2.92 & & & \\
friends & minority known (B) & 414 & 2.88 & 0.716 & 0.891 & \\
$N=1050$ & majority known (C) & 328 & 2.81 & & & \\
& sufficiently known (D) & 112 & 2.79 & & & \\
familiar & insufficiently known (A) & 202 & 3.23 & & & $\mathrm{~A}>\mathrm{B}$ \\
friends & minority known (B) & 412 & 3.17 & 0.291 & 2.084 & $\mathrm{~A}>\mathrm{C}$ \\
$N=1080$ & majority known (C) & 348 & 3.05 & & & $\mathrm{~A}>\mathrm{D}$ \\
& sufficiently known (D) & 118 & 3.11 & & & \\
intimate & insufficiently known (A) & 206 & 3.84 & & & $\mathrm{~A}>\mathrm{C}$ \\
friends & minority known (B) & 428 & 3.64 & $3.569^{*}$ & \multirow{2}{*}{$6.489^{*}$} & \\
$N=1106$ & majority known (C) & 354 & 2.53 & & & \\
& sufficiently known (D) & 118 & 3.39 & & & \\
romantic & insufficiently known (A) & 82 & 3.92 & & & \\
friends & minority known (B) & 222 & 3.67 & \multirow{2}{*}{0.655} & $0.007^{*}$ & \\
$N=536$ & majority known (C) & 172 & 3.42 & & & \\
& sufficiently known (D) & 60 & 3.77 & & & \\
\hline
\end{tabular}

${ }^{*} p<.05$. 
On another item about parental awareness, four groups on parental awareness of the content of adolescents' contacts with friends were independent variables. Mean scores on trust scale in each category of Facebook friends were still dependent variables for one-way ANOVA. The analytical results reveal that significant differences existed between four groups of the parental awareness in five categories of Facebook friends, "tending to strangers" category $(F=6.811, \mathrm{p}=0.000<0.05)$, "acquaintance friends" category $(F=5.502, \mathrm{p}=0.001<0.05)$, "familiar friends" category $(F=7.383, \mathrm{p}=0.000<0.05)$, "intimate friends" category $(F=9.816$, $\mathrm{p}=0.000<0.05)$, and "romantic friends" category $(F=2.832, \mathrm{p}=0.038<0.05)$. Because Levene's Test of Equality of Error Variances shows that the Levene's value for the "intimate friends" category (Levene's $=3.860, \mathrm{p}=0.009<0.05$ ) were significant, and the rest of those categories of Facebook friends were insignificant, post hoc tests in "intimate friends" category were followed by Games-Howell test, while the rest of categories used Schffe's test.

Table 3. Summary table of one-way ANOVA on various Facebook friends by parental awareness of the content of adolescents' contacts with friends

\begin{tabular}{|c|c|c|c|c|c|c|}
\hline $\begin{array}{c}\text { adolescents' } \\
\text { trust in }\end{array}$ & $\begin{array}{l}\text { tell parents about } \\
\text { Facebook use }\end{array}$ & $N$ & $M$ & $\begin{array}{c}\text { Levene's } \\
\text { test }\end{array}$ & $F$ & $\begin{array}{c}\text { Schffe's (Levene's } p>.05) \\
\text { Games-Howell (Levene's } p<.05)\end{array}$ \\
\hline \multirow{4}{*}{$\begin{array}{l}\text { tending to } \\
\text { strangers } \\
N=886\end{array}$} & tell parents nothing (A) & 248 & 2.72 & \multirow{4}{*}{0.576} & \multirow{4}{*}{$6.811^{*}$} & \multirow{4}{*}{$\begin{array}{l}A>D \\
B>D \\
C>D\end{array}$} \\
\hline & tell parents minority (B) & 360 & 2.64 & & & \\
\hline & tell parents majority (C) & 220 & 2.64 & & & \\
\hline & tell parents anything (D) & 58 & 2.13 & & & \\
\hline \multirow{4}{*}{$\begin{array}{l}\text { acquaintance } \\
\text { friends } \\
N=1050\end{array}$} & tell parents nothing (A) & 306 & 2.94 & \multirow{4}{*}{1.591} & \multirow{4}{*}{$5.502^{*}$} & \multirow{4}{*}{$\begin{array}{l}A>D \\
B>D \\
C>D\end{array}$} \\
\hline & tell parents minority (B) & 418 & 2.85 & & & \\
\hline & tell parents majority (C) & 244 & 2.89 & & & \\
\hline & tell parents anything (D) & 82 & 2.50 & & & \\
\hline \multirow{4}{*}{$\begin{array}{l}\text { familiar } \\
\text { friends } \\
N=1080\end{array}$} & tell parents nothing (A) & 310 & 3.24 & \multirow{4}{*}{0.629} & \multirow{4}{*}{$7.383^{*}$} & \multirow{4}{*}{$\begin{array}{c}\mathrm{A}>\mathrm{C}, \mathrm{A}>\mathrm{D} \\
\mathrm{B}>\mathrm{C}, \mathrm{B}>\mathrm{D} \\
\mathrm{C}>\mathrm{D}\end{array}$} \\
\hline & tell parents minority (B) & 428 & 3.21 & & & \\
\hline & tell parents majority (C) & 264 & 2.98 & & & \\
\hline & tell parents anything (D) & 78 & 2.85 & & & \\
\hline \multirow{4}{*}{$\begin{array}{l}\text { intimate } \\
\text { friends } \\
N=1106\end{array}$} & tell parents nothing (A) & 324 & 3.80 & \multirow{4}{*}{$3.860^{*}$} & \multirow{4}{*}{$9.816^{*}$} & \multirow{4}{*}{$\begin{array}{c}\mathrm{A}>\mathrm{C}, \mathrm{A}>\mathrm{D} \\
\mathrm{B}>\mathrm{D}\end{array}$} \\
\hline & tell parents minority (B) & 434 & 3.61 & & & \\
\hline & tell parents majority (C) & 266 & 3.53 & & & \\
\hline & tell parents anything (D) & 82 & 3.17 & & & \\
\hline \multirow{4}{*}{$\begin{array}{l}\text { romantic } \\
\text { friends } \\
N=536\end{array}$} & tell parents nothing (A) & 150 & 3.71 & \multirow{4}{*}{1.472} & \multirow{4}{*}{$2.832^{*}$} & \multirow{4}{*}{ n.s. } \\
\hline & tell parents minority (B) & 232 & 3.74 & & & \\
\hline & tell parents majority (C) & 124 & 3.45 & & & \\
\hline & tell parents anything (D) & 30 & 3.27 & & & \\
\hline
\end{tabular}

${ }^{*} p<.05$.

The results of post hoc comparisons exhibit in Table 3. The analytical results reveal that adolescents who told parents nothing about the content of Facebook use putted more trust than those who told parents anything in the "tending to strangers" category, "acquaintance 
friends" category, "familiar friends" category, and "intimate friends" category, of Facebook friends. As for "romantic friends" category, even though it was insignificant difference in trust between four groups of parental awareness, the mean scores on the trust scale in the four groups also exhibits a tendency, presenting that the mean score on the trust scale in the group of "talking about nothing" is more than those in the group of "talking about anything".

Similar to previous findings, the above results provide evidence, stating that adolescents who did not tell their parents about the content of Facebook use putted more trust in friends than those who told their parents about anything on Facebook.

\section{Conclusions and Discussion}

The present study aims to examine Taiwanese adolescents' trusts in various Facebook friends and the differences in those trusts between parental awareness of adolescents' Facebook use to contact friends. The study determines that adolescents putted trust in closer friends on Facebook. Moreover, the study concludes that Taiwanese adolescents who did not tell their parents about Facebook use putted higher trust in friends than those who told their parents about anything on Facebook.

As mentioned by Chou and Peng (2007), the majority of Taiwanese adolescents did not tell their parents about their online dating; while these adolescents trusted the built online friendships. The finding of the current study not only supports the above study by Chou and Peng, but also further suggests that the closer the friends were, the more trust adolescents putted in them, and the less awareness the adolescents' parents had.

The above findings are vital for social development of current adolescent. Facebook use facilitates adolescents' social development, providing opportunities to contact their known friends and some unfamiliar friends. Due to a lack of cognitive and/or emotional maturity, adolescents may be involved in a crisis situation in contacting friends for interaction. Theoretically, parental involvement can assist adolescents in building positive friendships with Facebook friends. The results of this study reveal that the more trust Taiwanese adolescents putted in friends, the less willing they were to tell their parents about the content of contacts on Facebook. In other words, adolescents contacted Facebook friends, having less parental involvement.

Moreover, the study categorized five types of Facebook friends based on the level of closeness. Of all types of friends, the number of friends in "acquaintance friends" category (1106/1120), "familiar friends" category (1080/1120), and "intimate friends" category $(1050 / 1120)$ were more than $90 \%$, suggesting that the majority friends of adolescents are average level of relationships. However, the number of "tending to strangers" category was calculated as about $80 \%$. Reasonably, adolescents may seldom contact the friends in "tending to strangers" category, resulting in that their trust in friends is the lowest rank-order. Furthermore, the number of romantic friends, the highest level of closeness, is approximately half. The contacts with romantic friends refer to a mutual attractive feeling (Connolly \& Konarski, 1994) with a passionate emotional desire, often involving a degree of physical closeness. The result of this study suggests that Taiwanese adolescents putted more trust in 
romantic friends than other categories of friends.

Adolescents make a friend through Facebook use to develop social skills, in which, they share information and sometimes disclosure themselves. During adolescence, the physical and emotional dependence of adolescent on their parents decreases and moves closer to the friends (Bester, 2007). Adolescents attempt to trust in peers for obtaining peer identification, and further to decrease the dependence on their parents (Zastrow \& Kirst-Ashman, 2010). Thus, adolescents tend to be not willing to tell their parents about contacts with friends. The above perspectives can explain why Taiwanese adolescents who did tell parents about Facebook use putted higher trust in friends than those who told their parents anything.

Trust benefits adolescents' social relationships, as mentioned by previous literature (Mietzner \& Lin, 2005; Peterson \& Behfar, 2003; Valenzuela, Park \& Kee, 2009). Adolescents put more trust in friends on Facebook than other social networking websites. However, an adolescent's thought and behavior are often affected by peers. During peer interactions, adolescents may learn some anti-social behaviors, such as deception, and even, drugs use (Zastrow \& Kirst-Ashman, 2010). Thus, as mentioned by McCarty et al. (2011), the higher trust they put in Facebook friends, more dangerous situation they would emerge in. The finding in the study reveals that the more trust Taiwanese adolescents tended to put in friends regardless of in which category of Facebook friends, the less willing they are to tell their parents about the content of contacts. Combing the finding in the study with the perspective by McCarty et al., the study identifies that adolescents using Facebook for contacting friends should be concerned. Moreover, a study by Liu et al. (2013) has reminded that if adolescents overly use Facebook for interactions, the interactions between adolescents and parents in real-life might be reduced. Since the majority adolescents are not willing to tell their parents about contacts with friends on Facebook, the parents need to be positively concerned their children on contacts with Facebook friends.

The study contributes to the literature by providing a viewpoint, more trust adolescents put in friends, less awareness their parents had, for adolescents using Facebook to contact friends. Future research should be done to explore the concrete content of contacts with Facebook friends for adolescents and to identify the associations between what they self-disclose to Facebook friends and why they are not willing to tell parents.

\section{Acknowledgements}

The authors would like to thank the National Science Council, Taiwan for financially supporting this research under Contract No. NSC 101-2410-H-018-030.

\section{References}

Ang, R. P., Chong, W. H., Chye, S., \& Huan, V. S. (2012). Loneliness and generalized problematic Internet use: Parents' perceived knowledge of adolescents' online activities as a moderator. Computers in Human Behavior, 28, 1342-1347. http://dx.doi.org/10.1016/j.chb.2012.02.019

Bester, G. (2007). Personality development of the adolescent: peer group versus parents. 
South African Journal of Education, 27(2), 177-190.

Braun, M. T. (2013). Obstacles to social networking website use among older adults. Computers in Human Behavior, 29(3), 673-680. http://dx.doi.org/10.1016/j.chb.2012.12.004

Chang, W. L., \& Lee, C. Y. (2013). Trust as a learning facilitator that affects students' learning performance in the Facebook community: An investigation in a business planning writing $\begin{array}{lllll}\text { course. Computers } \quad \& \quad \text { Education, } & 62, & 320-327 .\end{array}$ http://dx.doi.org/10.1016/j.compedu.2012.11.007

Chou, C., \& Peng, H. (2007). Net friends: Adolescents' attitudes and experiences vs. teachers' concerns. Computers in Human Behavior, 23(5), 2394-2413. http://dx.doi.org/10.1016/j.chb.2006.03.015

Cohen, L., Manion, L., \& Morrison, K. (2007). Research methods in education (6th ed.). NY: Rutledge.

Connolly, J., \& Konarski, R. (1994). Peer self-concept in adolescence: Analysis of factor structure and of associations with peer experience. Journal of research on Adolescence, 4, 385-403. http://dx.doi.org/10.1207/s15327795jra0403_3

Ellison, N. B., Steinfield, C., \& Lampe, C. (2007). The benefits of Facebook friends': social capital and college students' use of online social network sites. Journal of $\begin{array}{lll}\text { Computer-Mediated Communication, } & 12(4),\end{array}$ http://dx.doi.org/10.1111/j.1083-6101.2007.00367.x

Emily, C., Amy, M., \& Serge, D. (2009). Information disclosure and control on Facebook: Are they two sides of the same coin or two different processes? CyberPsychology \& Behavior, 12(3), 341-345. http://dx.doi.org/10.1089/cpb.2008.0226

Fogel, J., \& Nehmad, E. (2009). Internet social network communities: Risk taking, trust, and privacy concerns. Computers in Human Behavior, 25(1), 153-160. http://dx.doi.org/10.1016/j.chb.2008.08.006

Hsu, C. W., Wang, C. C., \& Tai, Y. T. (2011). The closer the relationship, the more the interaction on Facebook? Investigating the case of Taiwan users. Cyber Psychology, Behavior \& Social Networking, 14(7/8), 473-476. http://dx.doi.org/10.1089/cyber.2010.0267

Liau, A. K., Khoo, A., \& Ang, P. H. (2008). Parental awareness and monitoring of adolescent Internet use. Current Psychology, 27, 217-233. http://dx.doi.org/10.1007/s12144-008-9038-6

Liu, S. H., Yin, M. C., \& Huang, T. H. (2013). Adolescents' interpersonal relationships with friends, parents, and teachers when using Facebook for interaction. Creative Education, 4(5), 335-339. http://dx.doi.org/10.4236/ce.2013.45049

Ljepava, N., Orr, R. R., Locke, S., \& Ross, C. (2013). Personality and social characteristics of Facebook non-users and frequent users. Computers in Human Behavior, 29(4), 1602-1607. http://dx.doi.org/10.1016/j.chb.2013.01.026

McCarty, C., Prawitz, A. D., Derscheid, L. E., \& Montgomery, B. (2011). Perceived safety 
and teen risk taking in online chat sites. Cyber Psychology, Behavior, and Social Networking, 14(3), 169-174. http://dx.doi.org/10.1089/cyber.2010.0050

Mesch, G., \& Talmud, I. (2006). Online friendship formation, communication channels, and social closeness. International Journal of Internet Science, 1(1), 29-44.

Mietzner, S., \& Lin, L. W. (2005). Would you do it again? Relationship skills gained in a long-distance relationship. College Student Journal, 39(1), 192-200.

Ministry of Education. (2012). The amount of junior high school students and teachers in 101 academic year. Retrieved from https://stats.moe.gov.tw/files/main_statistics/details.xls.

Pempek, T. A., Yermolayeva, Y. A., \& Calvert, S. L. (2009). College students' social networking experiences on Facebook. Journal of Applied Developmental Psychology, 30(3), 227-238. http://dx.doi.org/10.1016/j.appdev.2008.12.010

Peterson, R. S., \& Behfar, K. J. (2003). The dynamic relationship between performance feedback, trust, and conflict in groups: A longitudinal study. Organizational Behavior and Human Decision $\quad$ Processes. 102-112. http://dx.doi.org/10.1016/S0749-5978(03)00090-6

Socialbakers.com (2013). Taiwan Facebook statistics by Country. Retrieved from http://www.socialbakers.com/facebook-statistics/taiwan

Subrahmanyam, K., Reich, S. M., Waechter, N., \& Espinoza, G. (2008). Online and offline social networks: Use of social networking sites by emerging adults. Journal of Applied Developmental Psychology, 29(6), 420-433. http://dx.doi.org/10.1016/j.appdev.2008.07.003

Valkenburg, P., \& Peter, J. (2007). Preadolescents' and adolescents' online communication and their closeness to friends. Developmental Psychology, 43, 267-277. http://dx.doi.org/10.1037/0012-1649.43.2.267

Valenzuela, S., Park, N., \& Kee, F. K. (2009). Is there social capital in a social network site? Facebook use and college students' life satisfaction, trust, and participation. Journal of Computer-Mediated Communication, $\quad$ 875-901. http://dx.doi.org/10.1111/j.1083-6101.2009.01474.x

Zastrow, C. H., \& Kirst-Ashman, K. K. (2010). Understanding human behavior and the social environment $\left(8^{\text {th }}\right)$. Belmont, CA: Brooks/Cole.

\section{Copyright Disclaimer}

Copyright reserved by the author(s).

This article is an open-access article distributed under the terms and conditions of the Creative Commons Attribution license (http://creativecommons.org/licenses/by/3.0/). 